\title{
Impact of Market Share on Profitability of Heavy Vehicles Manufacturers-A Case Study of Hino Pak Ltd
}

\author{
Muhammad Aqil, , Syed Fazal Aziz, Muhammed Dilshad ${ }_{3}$, Seemab Qadeer ${ }_{4}$ \\ ${ }^{1}$ (Assistant Professor, Commerce Department, Defence Authority Degree College, Karachi, Pakistan) \\ ${ }^{2}$ (Senior Executive Vice President(retd), National Bank of Pakistan, Karachi, Pakistan) \\ ${ }^{3}$ (Lecture, Government Degree College, Paretabad, Hyderabad, Pakistan) \\ ${ }^{4}$ (Assistant Professor, Economics Department, Defence Authority Degree College, Karachi, Pakistan)
}

\begin{abstract}
In the age of cut-throat competition, maximization of profit has become a challenging job for the firms. They always try to control those factors which influence their profitability. Before the phase of monitoring the determinants of profitability, this is inevitable to identify the factors which affect the firms' capability to earn profit. This paper addresses one of the important factors that is assumed to have high degree influence on the profit of firms. Market share of organizations have direct impact profitability on profitability. Therefore, in this paper, the effect of market share on the profitability of Heavy Vehicle Manufacturer i.e. Hino Pak Company limited. The correlation and regression analysis reveals that Market Share has a significant effect on Annual Profit, Return on Assets and Net Profit Margin. It means that greater the market share, greater the profitability of the firm.
\end{abstract}

Keywords: Heavy vehicle, Market Share, Net Profit Margin, Profitability, Return on Assets.

\section{Introduction}

Automobile industry is considered as the mother of all industries. Vehicles are manufactured by using steel, iron, aluminum, plastics, glass, carpeting, textiles, computer chips, rubber and many other materials. The industry gives birth to many other subsidiary industries such as auto parts, construction, steel, iron, electric, oil and gas industries. As a result, the auto sector contributes billions of dollars to GDP, it creates job opportunities for millions of people and it generates the domestic and foreign direct investment for a huge amount of money. According to an estimate, the manufacturing of sixty million vehicles engages about nine million people directly in making the vehicles and their spare parts [1]. This constitutes over five percent of the world's entire manufacturing employment. It is also estimated that every direct auto job supports at least another 5 indirect jobs in the country, resulting in more than fifty million jobs owed to the auto industry.

Therefore, this is very important to recognize the variables that determine the profitability of automobile firms. Researchers have always been looking for the real determinants of profitability. The purpose is to maximize the firms profit by monitoring variables that influence the profit. There are many internal and external factors that are responsible for firms profit and Market share is one of them. Market share of automobile companies enables the firm to book high sales volume and profits. A company with high market has more opportunity to book more and more profits.

The objective of this paper is to find out the relationship of market share on the profitability heavy vehicles manufactures by taking the case of Hino Pak Ltd as a sample.

\section{Review Of Literature}

There are many studies which addressed the relationship between market share and profitability. Buzzel, Gale and Sultan established that there is a positive relationship between these variables [2]. Rumelt (1991) also found a significant relationship between market share and profitability of firms [3]. Woo (1981) raised an objection on the relationship [4]. He admitted that there exists a relationship between them over a period of time, this phenomenon is generalized and over-extended without proper acknowledgement. Capon, Farley and Hoening in 1990 conducted a research find out the determinants of profitability of firms and found market share as one of the important one. Hergert (1984) took the sample of 5400 businesses and 76 industries. He found a weak and non-linear relationship between market share of the firm and its profitability [5].

Therefore, this is clear from the above discussion that the relationship between the two variables needs proper verification and data analysis in order to derive concrete conclusions.

\section{Research Methodology}

The data for 15 years i.e. from 1995-96 to 2009-10 has been obtained from the financial statements of Hino Pak Company Limited. The data contains Market share of the firm, profit, Return on Asset and Net Profit 
Margin. Profitability is measured by means of Annual Profit, Return on Asset and Net Profit Margin. The Independent Variable is Market Share and dependent variables are Annual Profit, Return on Asset, Return on Equity and Net Profit Margin. A correlation and regression analysis is conducted to find out the impact of market share on the dependent variables. SPSS software is used for data processing.

\section{Data Analysis}

The profitability is measured by means of Annual Profit, Return of Asset and Net Profit Margin. Return on Assets reflects the profit earned on the investment in assets. It is calculated with the help of following formula:

: $\quad$ ROA $=($ Net Profit After Tax/ Total Assets $) * 100$

Another important measure of profitability is Return on Equity that shows that profit earned on the investment of equity. Its formula is:

: $\quad \mathrm{NPM}=($ Net Profit After Tax/ Sales $) * 100$

The following table 1 reflects the data of the company over last fifteen years:

Table 1: Data for Hino Pak Company Ltd.

\begin{tabular}{|c|c|c|c|c|}
\hline Year & $\begin{array}{c}\text { Market Share } \\
(\text { In \%) }\end{array}$ & $\begin{array}{c}\text { Annual Profit } \\
\text { (In Rs. Million) }\end{array}$ & $\begin{array}{c}\text { ROA } \\
(\text { In \%) }\end{array}$ & $\begin{array}{c}\text { NPM } \\
(\text { In \%) }\end{array}$ \\
\hline $1995-96$ & 49.57 & 176.11 & 11.86 & 7.46 \\
\hline $1996-97$ & 40.62 & 56.90 & 3.23 & 2.41 \\
\hline $1997-98$ & 18.73 & -246.70 & -26.50 & -27.17 \\
\hline 1998-99 & 24.67 & -181.24 & -11.93 & -22.33 \\
\hline $1999-00$ & 40.10 & 4.79 & 0.38 & 0.33 \\
\hline $2000-01$ & 33.09 & 41.53 & 3.00 & 2.49 \\
\hline 2001-02 & 52.18 & 439.41 & 24.56 & 14.28 \\
\hline $2002-03$ & 48.30 & 352.13 & 11.71 & 8.26 \\
\hline 2003-04 & 66.08 & 335.73 & 9.82 & 6.08 \\
\hline 2004-05 & 51.62 & 242.96 & 7.67 & 3.82 \\
\hline 2005-06 & 40.35 & 323.88 & 7.82 & 5.07 \\
\hline $2006-07$ & 53.22 & 590.05 & 12.01 & 7.54 \\
\hline 2007-08 & 54.67 & 71.77 & 1.12 & 0.73 \\
\hline 2008-09 & 58.79 & 69.92 & 1.40 & 0.58 \\
\hline $2009-10$ & 59.58 & -148.07 & -2.58 & -1.33 \\
\hline
\end{tabular}

\subsection{Relationship between Market Share and Annual Profit}

In order to determine the relationship between the variables, following hypothesis are established: $\mathrm{Ho}=$ There is no relationship between Market Share and annual profit of Hino Pak Company Limited. $\mathrm{H} 1=$ There is a relationship between Market Share and annual profit of Hino Pak Company Limited. In order to test the hypothesis, the correlation between the variables is calculated which depicted in the following table 2 and this is clear from the above table that there is a significant correlation between Market and Annual Profit.

Table 2: Correlation Analysis

\begin{tabular}{|c|c|c|c|c|c|}
\hline & & MS & Profit & ROA & NPM \\
\hline \multirow[t]{5}{*}{ MS } & Pearson Correlation & 1 & $.537^{*}$ & $.652^{* *}$ & $.721^{* * *}$ \\
\hline & Sig. (2-tailed) & & .039 & .008 & .002 \\
\hline & $\mathrm{N}$ & 15 & 15 & 15 & 15 \\
\hline & Sig. (2-tailed) & .002 & .000 & .000 & . 000 \\
\hline & $\mathrm{N}$ & 15 & 15 & 15 & 15 \\
\hline
\end{tabular}

The following regression model is established:

$$
\text { : } \quad \mathrm{AP}=\mathrm{a}+\mathrm{b} \mathrm{MS}
$$

Where $\mathrm{AP}=$ Annual Profit

$\mathrm{a}=$ Intercept

MS= Market Share

$\mathrm{b}=$ slope 
Variables Entered/Removedb

\begin{tabular}{|l|l|l|l|}
\hline Model & Variables Entered & Variables Removed & Method \\
\hline 1 & MSa &. & Enter \\
\hline
\end{tabular}

a. All requested variables entered.

b. Dependent Variable: Profit

Model Summary

\begin{tabular}{|l|l|l|l|l|}
\hline Model & $\mathrm{R}$ & R Square & Adjusted R Square & $\begin{array}{l}\text { Std. Error of the } \\
\text { Estimate }\end{array}$ \\
\hline 1 & $.537 \mathrm{a}$ & .289 & .234 & 209.38800 \\
\hline
\end{tabular}

a. Predictors: (Constant), MS

ANOVA $^{b}$

\begin{tabular}{|ll|l|l|l|l|l|}
\hline Model & & Sum of Squares & Df & Mean Square & F & Sig. \\
\hline 1 & Regression & 231362.758 & 1 & 231362.758 & 5.277 & $.039^{\mathrm{a}}$ \\
& Residual & 569963.340 & 13 & 14 & & \\
\\
Total & 801326.098 & & & & \\
\hline
\end{tabular}

a. Predictors: (Constant), MS

b. Dependent Variable: Profit

Coefficients $^{\mathrm{a}}$

\begin{tabular}{|c|c|c|c|c|c|c|c|c|}
\hline \multirow{2}{*}{\multicolumn{2}{|c|}{ Model }} & \multicolumn{2}{|c|}{ Unstandardized Coefficients } & \multirow{2}{*}{$\begin{array}{l}\text { Standardized } \\
\text { Coefficients } \\
\text { Beta }\end{array}$} & \multirow[b]{2}{*}{$\mathrm{T}$} & \multirow[b]{2}{*}{ Sig. } & \multicolumn{2}{|c|}{ Collinearity Statistics } \\
\hline & & B & Std. Error & & & & Tolerance & VIF \\
\hline \multirow[t]{2}{*}{1} & (Constant) & -308.194 & 203.274 & & -1.516 & .153 & & \\
\hline & MS & 9.763 & 4.250 & .537 & 2.297 & .039 & 1.000 & 1.000 \\
\hline
\end{tabular}

a. Dependent Variable: Profit

\subsubsection{Interpretation}

: $\quad \mathrm{AP}=-308+9.763 \mathrm{MS}$

The single linear regression model reveals that the value of $\mathrm{R}$ square is 0.289 which means that there is a $28.9 \%$ variation in Annual Profit which is caused by Market Share. The value of F 5.277 with 0.039 p value which reflect that the model if fit for explaining the relationship.

The equation explains that if there is no market share, there will be an annual loss of Rs. 308 million. A rise in market share reduces the loss and if Market Share reaches more than 32\%, the loss will be converted to profit.

\subsubsection{Decision on the Hypothesis}

On the basis of above analysis, we reject the null hypothesis as there is a relation between Market Share and Profit.

\subsection{Relationship between Market Share and Return on Assets (ROA)}

In order to determine the relationship between the variables, following hypothesis established:

$\mathrm{Ho}=$ There is no relationship between Market Share and ROA of Hino Pak Company Limited.

$\mathrm{H} 1=$ There is a relationship between Market Share and ROA of Hino Pak Company Limited.

From Table 1, we can see that the market share and ROA are highly correlated. The regression Model is as follows:

The following regression model is established:

$$
R O A=a+b \text { MS }
$$

Where ROA= Return on Assets

$\mathrm{a}=$ Intercept

MS= Market Share

$\mathrm{b}=$ slope 
Variables Entered/Removed ${ }^{\mathbf{b}}$

\begin{tabular}{|l|l|l|l|}
\hline Model & Variables Entered & Variables Removed & Method \\
\hline 1 & MS $^{\mathrm{a}}$ &. & Enter \\
\hline
\end{tabular}

a. All requested variables entered.

b. Dependent Variable: ROA

Model Summary

\begin{tabular}{|l|l|l|l|l|}
\hline Model & $\mathrm{R}$ & R Square & Adjusted R Square & $\begin{array}{l}\text { Std. Error of the } \\
\text { Estimate }\end{array}$ \\
\hline 1 & $.652^{\mathrm{a}}$ & .425 & .381 & 9.22227 \\
\hline
\end{tabular}

a. Predictors: (Constant), MS

ANOVA $^{\text {b }}$

\begin{tabular}{|c|c|c|c|c|c|c|}
\hline \multicolumn{2}{|c|}{ Model } & Sum of Squares & Df & Mean Square & $\mathrm{F}$ & Sig. \\
\hline \multirow[t]{3}{*}{1} & Regression & 818.682 & 1 & 818.682 & 9.626 & $.008^{\mathrm{a}}$ \\
\hline & Residual & 1105.653 & 13 & 85.050 & & \\
\hline & Total & 1924.336 & & & & \\
\hline
\end{tabular}

a. Predictors: (Constant), MS

b. Dependent Variable: ROA

Coefficients $^{\mathrm{a}}$

\begin{tabular}{|c|c|c|c|c|c|c|}
\hline \multirow{2}{*}{\multicolumn{2}{|c|}{ Model }} & \multicolumn{2}{|c|}{ Unstandardized Coefficients } & \multirow{2}{*}{\begin{tabular}{|l}
$\begin{array}{l}\text { Standardized } \\
\text { Coefficients }\end{array}$ \\
Beta
\end{tabular}} & \multirow[b]{2}{*}{$\mathrm{T}$} & \multirow[b]{2}{*}{ Sig. } \\
\hline & & B & Std. Error & & & \\
\hline \multirow[t]{2}{*}{1} & (Constant) & -23.205 & 8.953 & & -2.592 & .022 \\
\hline & MS & .581 & .187 & .652 & 3.103 & .008 \\
\hline
\end{tabular}

a. Dependent Variable: ROA

\subsubsection{Interpretation}

$\mathrm{ROE}=-23.2+0.581 \mathrm{MS}-$

The single linear regression model reveals that the value of $\mathrm{R}$ square is 0.425 which means that there is a $42.5 \%$ variation in ROA which is caused by Market Share. The high $\mathrm{F}$ value reflects that the model is fit for explaining the relationship.

The equation explains that if there is no market share, the ROA will be $-23.2 \%$. A rise in market share reduces the negative return on Assets and if Market Share reaches more than $40 \%$, the negative return will be turned to positive.

\subsubsection{Decision on the Hypothesis}

On the basis of above analysis, we reject the null hypothesis as there is a relation between Market Share and ROA.

\subsection{Relationship between Market Share and Net Profit Margin(NPM)}

In order to determine the relationship between the variables, following hypothesis established:

$\mathrm{Ho}=$ There is no relationship between Market Share and NMP of Hino Pak Company Limited.

$\mathrm{H} 1=$ There is a relationship between Market Share and NMP of Hino Pak Company Limited.

From Table 1, we can see that the market share and NPM are highly correlated. The regression Model is as follows:

$$
\text { : } \quad \text { NPM }=\mathrm{a}+\mathrm{b} \text { MS }
$$

Where NPM= Net Profit Margin

$\mathrm{a}=$ Intercept

MS $=$ Market Share

$\mathrm{b}=$ beta or slope

Variables Entered/Removed ${ }^{\mathrm{b}}$

\begin{tabular}{|l|l|l|l|}
\hline Model & Variables Entered & Variables Removed & Method \\
\hline 1 & MS $^{\mathrm{a}}$ & & Enter \\
\hline
\end{tabular}

a. All requested variables entered.

b. Dependent Variable: NPM 


Model Summary
\begin{tabular}{|l|l|l|l|l|}
\hline Model & R & R Square & Adjusted R Square & $\begin{array}{l}\text { Std. Error of the } \\
\text { Estimate }\end{array}$ \\
\hline 1 & $.721^{\mathrm{a}}$ & .520 & .483 & 7.94640 \\
\hline
\end{tabular}

a. Predictors: (Constant), MS

ANOVA $^{\text {b }}$

\begin{tabular}{|c|c|c|c|c|c|c|}
\hline \multicolumn{2}{|c|}{ Model } & Sum of Squares & $\mathrm{df}$ & Mean Square & $\mathrm{F}$ & Sig. \\
\hline \multirow[t]{3}{*}{1} & Regression & 888.111 & 1 & 888.111 & 14.065 & $.002^{\mathrm{a}}$ \\
\hline & Residual & 820.889 & 13 & 63.145 & & \\
\hline & Total & 1709.000 & 14 & & & \\
\hline
\end{tabular}

a. Predictors: (Constant), MS

b. Dependent Variable: NPM

Coefficients $^{\mathrm{a}}$

\begin{tabular}{|c|c|c|c|c|c|c|}
\hline \multirow{2}{*}{\multicolumn{2}{|c|}{ Model }} & \multicolumn{2}{|c|}{ Unstandardized Coefficients } & \multirow{2}{*}{\begin{tabular}{|l} 
Standardized \\
Coefficients \\
Beta
\end{tabular}} & \multirow[b]{2}{*}{$\mathrm{t}$} & \multirow[b]{2}{*}{ Sig. } \\
\hline & & B & Std. Error & & & \\
\hline \multirow[t]{2}{*}{1} & (Constant) & -27.341 & 7.714 & & -3.544 & .004 \\
\hline & MS & .605 & .161 & .721 & 3.750 & .002 \\
\hline
\end{tabular}

a. Dependent Variable: NPM

\subsubsection{Interpretation}

$\mathrm{NPM}=-27.34+0.605 \mathrm{MS}$

The single linear regression model reveals that the value of $\mathrm{R}$ is 0.52 which means that there is a $52 \%$ variation in NPM which is caused by Market Share. The high F with only 0.002 level of significance reflects that the model is fit for explaining the relationship. Further, the value of $t$ also has $p$ value equal to 0.002 and if we reject the null hypothesis, the probability of committing type I error is just $0.2 \%$ which is almost negligible.

The equation explains that if there is no market share, the NPM will be $-27.34 \%$. A rise in market share reduces the negative value of NPM. If Market Share reaches more than $45 \%$, the negative return will be turned to positive.

\subsubsection{Decision on the Hypothesis}

On the basis of above analysis, we reject the null hypothesis as there is a relation between Market Share and NPM.

\section{Conclusion}

On the basis of above data analysis, we conclude that the Market Share has affected Annual Profit, ROA and NPM significantly. Hence the Market Share has a significant impact on the profitability of the firm.

\section{References}

[1] Organisation Internationale des Constructeurs d'Automobiles [OICA]. 2008. Retrieved March 3, 2014 from OICA website http://oica.net/category/economic-contributions/facts-and-figures/

[2] Buzzel, R.D., Gale, B.T., and Sultan, R.D.M.. Market Share-a key to profitability. Harvard Business Review. 1975 JanuaryFebruary, p 97-106.

[3] Rumelt, R.P. How much does industry matter? Strategic Management Journals, 1991. 12 p 167-185

[4] Woo, C.Y. Market Share Leadership-Does it always pay off? Proceedings of the Academy of Management. 1981. p 7-10.

[5] Hergert M. Market Share and Profitability: Is Bigger really better? Business Economics- 19. 1984. 45-48. 